\title{
Tiga Perempuan Pengusaha Batik: Kajian Peran Sosial Ekonomi Perempuan Pengusaha Batik di Kampung Batik Bubakan, Kelurahan Rejomulyo Semarang
}

\author{
Silfa Amalia, Suyanto, Eko Punto Hendro \\ Program Studi Antropologi Sosial, Fakultas Ilmu Budaya, Universitas Diponegoro \\ J1. Prof. Soedarto, SH. Tembalang Semarang 50275 \\ Email: silfaamalia29@gmail.com
}

\begin{abstract}
Abstrak
Partisipasi perempuan dalam pembangunan sangat diperlukan, baik dalam rumah tangga maupun dalam kehidupan bermasyarakat dan bernegara. Keterlibatan wanita dalam kerja produktif akan menimbulkan perubahan sosial, karena salah satu wujud perubahan sosial adalah perubahan dalam kerja, khususnya untuk wanita di Jawa. Tujuan penelitian ini adalah untuk mengetahui faktor pendorong perempuan menjadi pengusaha batik, mengetahui peranan sosial ekonomi perempuan pengusaha batik, baik dalam kegiatan rumah tangga, masyarakat maupun kegiatan usaha batik, serta mengetahui proses pengambilan keputusan dan pengalokasian waktu para perempuan pengusaha batik. Teori yang digunakan dalam penelitian ini adalah teori kebutuhan dan prestasi dari David McClelland dan teori peran perempuan oleh Caroline O.N. Moser. Penelitian ini dilakukan dengan metode observasi partisipan dan menggunakan pendekatan kualitatif. Teknik pengumpulan data yang dilakukan adalah dengan menggunakan observasi (pengamatan), wawancara mendalam, dokumentasi, studi literatur dan triangulasi. Informan berjumlah tiga orang yang diperoleh dengan kriteria perempuan yang memiliki home industry/ usaha batik. Berdasarkan penelitian yang dilakukan dapat disimpulkan bahwa perempuan tidak hanya memainkan peranannya sebagai ibu rumah tangga, mereka juga banyak terlibat dalam kegiatan usaha dan aktif dalam kegiatan sosial kemasyarakatan. Dalam pengalokasian waktu diketahui beban kerja perempuan lebih panjang. Bahkan perempuan pengusaha batik memegang peranan sentral dalam hal pengambilan keputusan dalam perekonomian rumah tangga.
\end{abstract}

Kata Kunci: peran sosial ekonomi perempuan, pengusaha batik,alokasi waktu, pengambilan keputusan.

\section{Abstract}

Women's participation in the development of household, social life, and country life is most needed. Women's involvement in productive work will lead to social change due to a kind of social change is change in the work, especially for women in Java. The aims of this study are to find out the supporting factors of women being Batik businesswomen, a socio-economic role of batik businesswomen in household, society, or business activity of Batik, the decision making process, and time allocation of Batik businesswomen. The theories of this study are needs and achievements theory of David Mc Clelland and role theory of Caroline O.N Moser. This study was conducted by 
using participant observation method and qualitative approach. The data collection techniques are observation, in-depth interview, documentation, literature study, and triangulation. The Informants are three women obtained by the criteria of women who have home industry or Batik industry. Based on this study can be concluded thatwomen are not only having a role in housewives but also they have involvement in a business activity or social. In allocating time it is known that women's workload is longer. Even women batik entrepreneurs hold a central role in terms of decision making in the household economy.

Keywords: women socio-economic role, Batik entrepreneur, allocation time, decision-making.

\section{Pendahuluan}

Batik di Indonesia merupakan sebuah karya seni yang sudah ada sejak jaman Kerajaan Majapahit dan sejak saat itu batikpun terus berkembang hingga pada jaman kerajaan berikutnya. Kesenian batik secara umum meluas di Indonesia dan secara khusus di pulau Jawa setelah akhir abad ke-18 atau awal abad ke-19 sampai sekarang, tetapi selama ini masyarakat Indonesia lebih mengenal batik dari daerah seperti Pekalongan, Yogyakarta, Solo dan Lasem. Tidak seperti kotakota tersebut, batik di kota Semarang sampai saat ini masih kurang populer di telinga masyarakat umum. Padahal, batik di kota Semarang sudah dimulai sejak sebelum jaman penjajahan Jepang, sehingga dapat dikatakan bahwa batik di kota Semarang telah melaluiperjalanan sejarah yang cukup panjang, bahkan nilai-nilai serta ciri-ciri yang khas dan unikyang ada pada batik telah mengakar. Mulanya, batik tulis hanya bisa dibuat oleh putri-putri keraton untuk mengisi waktu luang, lalu dilakukan juga oleh abdi dalem beserta orang-orang terdekat keluarga keraton (Yahya, 1971: 24).

Kontribusi wanita dalam produktivitas kerja akan menyebabkan terjadinya perubahan sosial, hal ini terjadi karena salah satu bentuk perubahan sosial merupakansuatu bentuk perubahan dalam kerja, khususnya bagi wanita Jawa. Terlibatnya perempuan dalam dunia kerjabisa berdampak padaaktivitas perekonomian rumahtangga, kemudian terjadilah perubahan struktur ekonomi dalam keluarga (Wisadirana, 2004). Peran perempuandalam mengurus rumah tangga, di samping mengelola kegiatan rutin keluarga, juga terkadang harus bekerja demi mencari pemasukan tambahan dalam kebutuhan rumahtangga. Dalam aktivitas tersebut, peran perempuanterbilang cukup besar, terutama dalam proses pengambilan keputusan yang berhubungan dengan berbagai aktivitas sosial, ekonomi, dan rumah tangga. Di perkotaan, perempuan berperan melalui lembaga-lembaga yang ada, seperti kelompok PKK. Meskipun demikian, hal ini tidak menutup kemungkinan partisipasi wanita dalam kelompok kerja lain yang tampak dalam masyarakat, seperti kelompok arisan, Dharma Wanita, kelompok pengajian, dan sebagainya.

Peran perempuan dalam bidang perekonomian bukan suatu hal yang baru. Kegiatan ekonomi perempuan tertua yang telah lama dilakukan berada di bidang pertanian. Dalam perkembangannya, peran wanita cukup aktif dalam kegiatan ekonomi atau membanjiri pasar kerja di pabrik-pabrik (Boserup, 1984: 100-110). Isu tersebut telah menunjukkan bahwa peranan perempuan tidak terpaku pada ranah rumahtangga saja, melainkan dapat melakukan kegiatan produktif di luar rumah. Umumnya, suamiadalah seseorang yang menjadi tulang punggung keluarga, namun seiring berkembangnya zaman, justru perempuanikut bekerja dan berperan dalam pemenuhan kebutuhan ekonomi keluarga. Alasan yang membuat wanita ikut berkecimpung dalam mencari nafkah tidak asing lagi, disamping untuk pemenuhan kebutuhan hidup bagi keluarga, selain itu juga sebagai 
aktualisasi diri bagi wanita itu sendiri jika berhasil dan sukses dalam pekerjaannya. Meskipun seorang suami berkewajiban memenuhi kebutuhan materi keluarga, ada alasan lain yaitu agarwanitabisa lebih dihargai dan mendapat pengakuan dalam lingkungan masyarakatnya. Menurut Stoler (1984: 53) perdagangan berskala kecil dapat dipastikan berada di tangan perempuan yang berasal dari rumah tangga yang relatif miskin. Dengan mengalokasikan sumber yang dimilikinya, seperti energi, waktu, keterampilan, dana yang kecil, bersama dengan anggota keluarga mereka dapat bekerja untuk memenuhi kebutuhan pokoknya. Dalam hal menetapkan perananwanita sebagai ibu rumahtangga, berarti bahwa tempat dan kewajiban seorang istri hanya berkutatdalam sektor domestik saja. Hal ini berartiwanita hanya berkecimpung di dalam rumah, sektor privat, tanpa mempunyai kedudukan formal di masyarakat. Seorang perempuan di dalam masyarakat memiliki kedudukan resmi yaitu sebagai istri (Sadli, 2010: 172).

Dalam rangka mempelajari partisipasi perempuan, khususnya peranan sosial ekonomi perempuan pengusaha batik,untuk dapat mencapai hal tersebut diperlukan pendekatan antropologis, hal ini dikarenakan terkait dalam masalah usaha untuk mempertahankan kelangsungan hidup. Selain itu, aktivitas perempuan sebagai pengusaha batik tidak hanya menyangkut gambaran mengenai kehidupan mereka saja, melainkan juga mengenai kondisi sosial budaya yang mendukung berlangsungnya aktivitas tersebut. Seperti halnya dalam proses pembuatan batik, banyak diperlukan tenaga kerja perempuan dari awal produksi sampai akhir produksi hingga ke pemasarannya.

Perempuan bekerja saat ini bukanlah masalah baru, adapun beberapa keputusan untuk memilih bekerja itu, didasari oleh beberapa faktor diantaranya:

Menambah pendapatan keluarga (family income) terutama jika pendapatan suami relative kecil. Memanfaatkan berbagai keunggulan (pendidikan, keterampilan) yang dimilikinya yang diharapkan oleh keluarganya. Menunjukkan eksistensi sebagai manusia (aktualisasi diri) bahwa ia mampu berprestasi dalam kehidupan masyarakat. Untuk memperoleh status atau kekuasaan lebih besar didalam kehidupan keluarga. (Suhendi, 2001: 56).

Dewasa ini sudah banyak wanita yang terjun kedalam Usaha Mikro, Kecil dan Menengah (UMKM). UMKM di beberapa negara berkembang, seringkali dikaitkan dalam upaya pemerintahuntuk mengatasi permasalahan ekonomiataupun sosial antara lain, seperti meminimalkan angka pengangguran, memberantas kemiskinan, serta memeratakan pendapatan. Bahkan dengan adanya UMKM di Indonesia ini merupakan suatu langkah strategis dalam rangka peningkatan perekonomian. Hal ini bisa kita lihatdari kekuatan UMKM yang terbukti sebagai tembok pengaman dalam sektor perekonomian di saat perusahaan besar mengalami gulung tikar ketika krisis ekonomi melanda di Indonesia. Bahkan UMKM sanggup memberikan sumbangan dalam memperbaiki perekonomian nasional (National Economic Recovery) (Wiryanto, 2011).

Berdasarkan permasalahan di atas, maka peneliti merasa perlu untuk melakukan penelitian yang berkaitan dengan judul: " Tiga Wanita Pengusaha Batik (Peran Sosial Ekonomi Wanita Pengusaha Batik di Kampung Batik Bubakan, Kelurahan Rejomulyo Semarang)".

\section{Metode}

Penelitian ini dilakukan dengan metode observasi partisipan dan menggunakan pendekatan kualitatif. Teknik pengumpulan data yang dilakukan adalah dengan menggunakan observasi (pengamatan), wawancara mendalam, dokumentasi, studi literatur dan triangulasi. Informan berjumlah tiga orang yang diperoleh dengan kriteria perempuan yang memiliki home industry/ usaha batik. 


\section{Hasil dan pembahasan}

\subsection{Faktor Pendorong Perempuan Menjadi Pengusaha Batik}

Pengusaha perempuan memiliki dampak yang signifikan terhadap ekonomi, bukan hanya dalam kemampuan untuk menciptakan pekerjaan untuk diri sendiri namun juga untuk menciptakan pekerjaan bagi orang lain. Berwirausaha tidak hanya dimiliki oleh para lelaki, tetapi wanita pun saat ini sudah mulai membuat suatu usaha yang dapat dijadikan tumpuan hidupnya. Pada saat ini wanita tidak lagi hanya berperan sebagai ibu rumah tangga dan bergantung pada suaminya, namun telah aktif berperan dalam berbagai bidang kehidupan, baik sosial, ekonomi, maupun politik. Wanita termasuk salah satu komponen penting yang diharapkan dapat mengisi pembangunan.

Pada umumnya wanita bekerja atau tidak bekerja bukan hanya tergantung pada pekerjaannya saja, akan tetapi lebih bergantung pada wanita yang melakukan pekerjaan itu. Sehingga, wanita bekerja dengan etos kerja yang tinggi (terkait dengan disiplin dan ketrampilan serta semangat yang sangat tinggi) hal ini karena selain panggilan ekonomi untuk mencari nafkah dan juga karena adanya panggilan moral serta status sosial diri dan keluarganya dalam masyarakat. Hal ini juga berarti semakin meningkatnya penghasilan yang mereka terima, sehingga baik secara langsung maupun tidak langsung jelas akan meningkatkan penghasilan bagi dirinya dan keluarganya. Suatu badan usaha yang dimulai oleh wanita sangat dipengaruhi keputusan maupun keinginan dari anggota keluarga lainnya. Wanita yang memperoleh dukungan dari keluarga dapat mengelola badan usahanya dengan sukses (Rajani dan Sarada, 2008: 58).

Faktor yang mendorong wanita dalam menciptakan usaha yaitu untuk menentukan apa yang ingin ia capai, serta produk apa yang akan dihasilkan. Berbagai macam faktor yang dapat memotivasi wanita dalam menciptakan usaha yaitu karena ingin menciptakan lapangan pekerjaan sendiri untuk mengurangi pengangguran, serta menunjukkan bahwa wanita sadar akan kondisi pengangguran yang semakin meningkat, kesadaran diri dari wanita semacam ini dapat memotivasi dirinya bahwa wanita sekarang tidak hanya mampu bekerja namun juga mampu menciptakan pekerjaan.

Berdasarkan fakta hasil lapangan, bahwa dalam keluarga perempuan pengusaha batik di Kampung Batik Bubakan Semarang tidak lagi adanya anggapan bahwa perempuan hanya bekerja menyelesaikan pekerjaan rumah tangga dan mengurus anak saja, namun perempuan juga ikut berpartisipasi dalammeningkatkan pendapatan bagi keluarga mereka. Oleh karena itu kepemilikan peran perempuan di sektor publik yaitu dengan menjadi pengusaha batik menunjukkan adanya perubahan konstruksi sosial dalam masyarakat mengenai pembagian kerja secara seksual. Keikutsertaan perempuan dalam memenuhi kebutuhan hidup keluarga, secara sadar ataupun tidak, perempuan pengusaha batik telah memiliki peran ganda.

Peran utama yang dilekatkan oleh masyarakat mengenai ibu rumah tangga, bahwa mereka seolah-olah telah membuat suatu kesepakatan yakni perempuan tugas utamanya adalah pekerjaan dalam ranah domestik, seperti memasak, mencuci, mengurus anak dan lainnya. Namun, justrupara perempuan pengusaha batik di Kampung Batik Semarang merupakan salah satu pelaku utama yang berperan penting dalam perkembangan usaha batik mereka. Perempuan pengusaha batik ini merupakan perempuan-perempuan yang terampil dalam mengelola usahanya, sejak dari proses membatik, memasarkan, mengelola keuangan hingga mengembangkan usaha.

Faktor lain yang melatar belakangi wanita menjadi pengusaha batik sebagai pengusaha batik, dengan membuka usaha di rumah, mereka dapat memiliki banyak waktu luang dan bebas untuk 
membicarakan persoalan seputar bisnis batiknya dengan keluarga. Merasa hidup lebih sejahteradikarenakan urusan keluarga dan urusan bisnis tidak terdapat jarak pemisah yang cukup berarti. Menciptakan suatu industri rumahan juga dapat dijadikan dalam mengatur tenaga dengan lebih efektif. Industri rumahan seperti industri batik ini misalnya, ibaratnya tidak menjadi kegiatan bisnis semata, namun sekaligus menjadi ruang rekeratif. Pengusahabatik dapat melakukan pekerjaannya kapan saja, hal tersebut yang menyebabkan membuka bisnis di rumah lebih menguntungkan dibandingkan bisnis di luar rumah karena dapat memanfaatkan waktu sebaik mungkin.

Hal tersebut diatas dapat dikaitkan dengan teori kebutuhan dan prestasi dari David McClelland (1971). Menurut McClelland bahwa agar kita berhasil dalam suatu pekerjaan, yang paling penting adalah sikap kita terhadap pekerjaan yang kita tekuni. Kemudian dari sini, McClelland membuat suatu konsep yang cukup terkenal, yang disebut denganthe need for Achievement, kebutuhan atau dorongan untuk berprestasi. Yang kemudian, konsep ini disingkat dengan n-Ach. Orang yang memiliki n-Ach tinggi, dan juga memiliki kebutuhan untuk berprestasi, maka akan mengalami kepuasan batin pada diri orang tersebut, bukan karena mendapatkan imbalan dari hasil kerjanya, namun karena hasil kerja tersebut dianggapnya sangat baik dan berjalan lancar. Ada kepuasan batin tersendiri jika seseorang tersebut berhasil menyelesaikan pekerjaannya dengan sempurna. Imbalan material menjadi faktor sekunder. Dengan konsep n-Ach ini, kita lihat pengaruh Max Weber terhadap McClelland. Selanjutnya McClelland mengatakan bahwa jika dalam sebuah masyarakat terdapat banyak orang yang memiliki n-Ach tinggi, maka dapat diharapkan masyarakat tersebut akan menghasilkan pertumbuhan ekonomi yang tinggi pula. Dengan demikiann, terdapat korelasi antara tingkat n-Ach dengan keberhasilan pertumbuhan ekonomi.

.Dari penjelasan di atas dapat disimpulkan bahwa terdapat beberapa faktor pendorong wanita menjadi pengusaha batik, antara lain, untuk meningkatkan pendapatan, membuktikan kemampuan dalam berwirausaha, sebagai kepuasan terhadap diri sendiri, agar mendapat pengakuan sosial, menggunakan pengalaman yang telah didapat, dapat mengatur waktu sendiri dan bisa lebih dekat dengan keluarga, menyediakan pekerjaan untuk anggota keluarga, membangun usaha untuk jangka panjang

\subsection{Peran Sosial Ekonomi Perempuan Pengusaha Batik}

Peran perempuan dalam industri batik begitu besar, bahkan keterlibatan kaum perempuan dalam usaha semacam ini merupakan alternatif untuk meningkatkan taraf hidup mereka. Dalam usaha kecil seperti usaha batik mereka ini, perempuanberperan sebagai pelaku usaha atau sebagai pemilik, sebagai manager ataupun sebagai tenaga kerja. Meskipun waktu mereka banyak dihabiskan dalam kegiatan usaha, namun bukan berarti mereka melupakan kewajibannya dalam rumah tangga.

Teori peran yang digunakan dalam penelitian ini adalah Triple's Woman Role oleh Caroline O.N. Moser dalam buku A Guide to Gender-Analysis Frameworks yang ditulis oleh Candida March, Ines Smyth, dan Maitrayee Mukhopadhyay (1999, 56-57), terdapat tiga peran perempuan yang diungkapkan Moser, antara lain peran reproduktif, peran produktif dan peran perempuan dalam kehidupan bermasyarakat.

Pada bagian ini dibahas alasan mereka bertahan melakukan pekerjaan sebagai pengusaha batik yang keuntungannya tidak dapat dipastikan serta dibutuhkan banyak modal. Di samping itu pula, dibahas mengenai strategi yang digunakan untuk mempertahankan usaha serta kendala-kendala yang menyebabkan mereka berperan dalam berbagai hal. Kemudian pembagian ruang sosial antara-

Tiga Perempuan Pengusaha Batik (Peran Sosial Ekonomi Perempuan Pengusaha 
laki-laki dan perempuan yang mengakibatkan adanya ketimpangan gender yang ada dalam pembagian tugas dalam ranah domestik dan publik antara laki-laki (suami) dan perempuan (istri). Oleh karena itu, pembahasan ini dimulai dari kegiatan mereka dalam rumah tangga dan diakhiri dengan kegiatan lain di luar rumah tangga dan usahanya.

\section{1) Pengusaha Batik dalam Kegiatan Rumah Tangga (Reproduktif)}

Kegiatan rumah tangga tetap merupakan tugas perempuan dalam masyarakat di Kampung Batik Bubakan Semarang, yaitu mengasuh dan mendidik anak. Ini bukan berarti mereka dalam sehari penuh mengasuh putra-putrinya, melainkan yang terpenting adalah membentuk pribadinya, terutama mengarahkan ke hal-hal yang positif. Dalam menjalankan peranannya, para pengusaha batik di Kampung Batik Semarang mengerjakan pekerjaan rumah tangganya sendiri. Namun terkadang dibantu oleh anak mereka, seperti menyetrika pakaian, menyapu lantai, mencuci piring, dan menata rumah. Kegiatan semacam ini diajarkan kepada anak mereka dalam proses sosialisasi. Setiap orang tua selalu mengajarkan dan menyuruh anak mereka untuk melakukan aktivitas tersebut. Namun kegiatan rumahtangga tersebut dominan dilakukan oleh istri.

Hal yang sangat menonjol dari perempuan pengusaha batik di Kampung Batik Bubakan Semarang ini adalah bahwa mereka mempunyai peranan yang sentral dalam mengalokasikan sumber ekonomi untuk keperluan anggota keluarga dan kegiatan usahanya. Selain itu, dalam hal urusan rumah tangga juga mereka sangat berperan dalam segala bidang kegiatan, hal ini karena berhubungan dengan anggaran belanja yang dipegang oleh wanita/ istri.

\section{2) Pengusaha Batik dalam Kegiatan Usaha (Produktif)}

Ibu rumah tangga yang bekerja yaitu seorang wanita yang berprofesi sebagai ibu rumah tangga dan juga memiliki peran sebagai seorang pengusaha, di mana faktor yang mendorong ibu rumah tangga yang bekerja adalah agardapat hidup mandiri dan berkeinginan untuk memperbesar penghasilan keluarga disamping penghasilan dari suami, dan sebagai rasa kepuasan diri sendiri apabila dapat menjalankan suatu usaha itu sendiri yang berjalan dengan baik.

Di daerah penelitian terlihat bahwa keterlibatan perempuan dalam mencari nafkah mempunyai arti tersendiri dalam keluarganya. Menurut mereka, perempuan tidak harus selalu tinggal diam di rumah. Mereka dapat bebas pergi kemana saja, justru mereka sering keluar rumah untuk mencari ide dan pasaran yang sedang laku. Dengan cara demikian, seringkali mereka dapat informasi untuk kemajuan usahanya. Di lain pihak, ternyata dengan pergi ke pasar dirasakan lebih menyenangkan daripada tinggal diam di rumah, sehingga mereka dapat memperoleh uang serta mempunyai banyak link atau kenalan. Di Kampung Batik Bubakan Semarang, pada umumnya semua keuangan yang mengatur adalah istri mereka, begitupun dengan penghasilan yang diterima oleh istrinya. Suami jarang menerima penghasilan tersebut.

Selain itu, salah satu hal yang terpenting bagi pengusaha batik yaitu strategi mereka dalam aktivitas usaha. Setiap perusahaan selalu mempunyai strategi yang berbeda-beda. Akan tetapi, para pengusaha batik mempunyai strategi yang dapat dikatakan sama, bahkan dalam hal kemampuan berproduksi tiap pengusaha memiliki kesamaan. Di Kampung Batik Bubakan Semarang ini dikenal dua musim pasaran, yaitu musim sepi dan musim ramai. Pada saat musim sepi, jumlah produksi mereka akan menurun, musim sepi biasanya jatuh saat awal-awal memasuki bulan puasa sampai pertengahan bulan puasa. Kemudian h-3 menjelang hari Raya Idul Fitri biasanya akan ramai kembali. Pada musim ramai, mereka dapat memproduksi dalam jumlah yang banyak. Pada musim ini, mereka berusaha sekuat tenaga menurut kemampuannya untuk memproduksi kain batik. Jika 
pada akhir musim itu jumlah produksi masih banyak, maka dapat digunakan untuk persediaan pada musim-musim sepi.

\section{3) Pengusaha Batik dalam Kegiatan Masyarakat}

Dalam kehidupan bermasyarakat, interaksi antara keluarga merupakan bagian yang sangat penting. Jika tidak ada kegiatan lain pada malam hari, seperti menyiapkan hasil produksi yang dipesan pelanggan maupun nyanthing, mereka berbincang-bincang dengan anggota keluarga. Para perempuan pengusaha batik di Kampung Batik Bubakan Semarang ini juga sering terlibat perbincangan dengan tetangga-tetangga terdekat mereka.

Di luar kegiatan rumah tangga dan usaha, terdapat beberapa kegiatan yang diikuti oleh pengusaha batik seperti dalam pesta perkawinan, arisan, selamatan, pengajian, PKK, BKM (Badan Keswadayaan Masyarakat) bahkan melayat. Hubungan antaranggota keluarga dalam kehidupan bermasyarakat dalam bentuk pertemuan RT, pertemuan yang bersifat keagamaan, bahkan pertemuan-pertemuan yang telah disebutkan diatas tadi dipandang sangat penting dalam kehidupan bermasyarakat. Bagi wanita yang bekerja seperti pengusaha batik ini tentunya pengaturan waktu akan sangat penting sekali antara kegiatan rumah tangga, bekerja dan kegiatan sosial kemasyarakatan.

Ketika seseorang tidak mengikuti kegiatan sosial kemasyarakatan, maka seringkali seseorang akan merasa diasingkan dari lingkungannya. Hal ini tentunya bagi masyarakat yang tinggal di perkampungan seperti para wanita pengusaha batik di Kampung Batik Bubakan ini merupakan beban yang sangat berat. Solidaritas sosial diantara mereka juga sangat tinggi. Hal ini dibuktikan dengan kebiasaan memberikan sumbangan apabila ada rekan mereka yang sakit ataupun meninggal. Demikian juga kalau ada yang mempunyai gawe seperti mantu, teman-teman mereka juga akan nyumbang kepada yang memiliki gawe tersebut. Kegiatan-kegiatan di luar rumah tersebut diikuti secara rutin oleh pengusaha batik di Kampung Batik Bubakan Semarang jika tidak ada kegiatan penting dalam aktivitas usahanya.

\subsection{Pengusaha Batik dalam Wujud Pengambilan Keputusan}

Perempuan sebagai ibu rumah tangga yang mengelola kegiatan rutin rumah tangga dan sebagai pencari nafkah, tidak ketinggalan perannya dalam pengambilan keputusan. Di Kampung Batik Bubakan Semarang ini, para perempuan pengusaha batik memiliki peranan yang kuat dalam pengambilan keputusan untuk aktivitas produksi batik, pemasaran, penentuan uang modal dan aktivitas rumah tangga. Hal ini karena mereka memiliki wewenang dalam mengatur perekonomian keluarga. Di Kampung Batik Semarang sendiri, dalam lingkup rumah tangga, keputusan istri cenderung lebih berperan. Sebaliknya, keputusan suami lebih berperan pada lingkup yang lebih luas, seperti yang berhubungan dengan masyarakat ataupun ranah publik lainnya.

Keterlibatan perempuan yang bekerja dalam usaha batik akan memperbesar sumbangannya terhadap ekonomi rumah tangga. Kondisi ini menempatkan perempuan pada posisi yang mempunyai kekuatan untuk tawar-menawar dengan suami dalam setiap pengambilan keputusan. Mereka mempunyai otonomi untuk memutuskan persoalan-persoalan rumah tangganya tanpa selalu tergantung pada keputusan suami. Suami mereka cenderung tidak berani bertindak sewenangwenang terhadap istri, karena istri yang bekerja memiliki otonomi untuk memutuskan persoalan tersebut. Pada dasarnya, proses pengambilan keputusan yang berhubungan dengan sumber ekonomi keluarga di Kampung Batik ini, baik dalam kegiatan rumah tangga, usaha dan masyarakat, adalah 
sama, karena perempuan pengusaha batik mempunyai wewenang sentral dalam mendistribusikan sumber ekonomi keluarga.

\subsection{Alokasi Waktu}

Kontribusi perempuan dalam kehidupan berumah tangga tentu tidak boleh dipandang sebelah mata, hal ini bisa dilihat dari kontribusi pendapatannya, bahkan sebenarnya ketika tidak bekerja pun mereka telah berkontribusi melalui alokasi waktunya, terutama dalam kegiatan domestik. Selain mengalokasikan waktunya dalam kegiatan rumah tangga, seringkali perempuan harus mencurahkan waktu untuk kegiatan usaha maupun di luar usaha. Mereka harus benar-benar dapat membagi pencurahan waktu tersebut agar semua peran dapat dijalankannya dengan baik.

Di Kampung Batik Bubakan Semarang, ketiga pengusaha tersebut dalam hal alokasi waktu yang dibutuhkan dalam kegiatan rutin rumah tangga ternyata lebih besar. Dari ketiga informan tersebut, waktu yang dibutuhkan yakni 10 sampai 11 jam per hari. Hal ini karena seluruh kegiatan rumah tangga dikerjakan sendiri, terkadang dibantu anak dan suaminya. Dengan demikian, waktu yang digunakan untuk kegiatan usaha cenderung lebih sedikit, yaitu 7-8 jam per hari. Di Kampung Batik Bubakan, total kerja istri relatif lebih banyak dibandingkan dengan suami. Porsi terbesar curahan waktu bekerja bagi suami hanya pada pekerjaan mencari nafkah di luar industri rumahtangga.

\section{Simpulan}

Berdasarkan hasil penelitian dan pembahasan di atas maka dapat ditarik kesimpulan bahwa Faktor yang melatarbelakangi perempuan menjadi pengusaha batik ternyata agar lebih mandiri dan mampu mengambil keputusannya sendiri dalam menggunakan uang karena mereka juga bekerja dan memiliki uang mereka sendiri, kemudian adanya kepuasan batin bahwa dirinya mampu dalam mengelola suatu usaha dan agar mendapatkan pengakuan sosial. Bagi sebagian perempuan kelas menengah dan ke atas, bahwa bekerja sudah dianggap sebagai sarana untuk mengekspresikan diri bahkan sebagai sarana untuk menjalin komunikasi dengan dunia luar. Satu hal lain yang dapat mendukung keinginan perempuan untuk bekerja adalah adanya pandangan bahwa bekerja merupakan wujud partisipasi nyata dari perempuan. Industri rumahtangga batik ini sendiri menjadi wahana bagi perempuan untuk berperan ganda, mengerjakan tugas domestik dan sebagai wahana pemenuhan kebutuhan hidup.

Peran sosial ekonomi perempuan pengusaha batik di Kampung Batik Bubakan, yaitu baik dalam kegiatan reproduktif, kegiatan usaha batik (produktif), maupun masyarakat, serta peran perempuan dalam wujud pengambilan keputusan pada usaha batik dan rumah tangga dari penelitian yang dilakukan bahwa, dalam melakukan kegiatan rumah tangga, meskipun mereka disibukkan dengan kegiatan usaha batiknya akan tetapi mereka sering dituntut untuk berperan ganda dalam keluarga. Mereka masih harus tetap menjalankan tugas domestiknya. Peranan tersebut merupakan suatu bentuk perilaku yang termanifestasi dalam usaha mereka memenuhi kebutuhan hidup anggota keluarga. Kemudian dalam kegiatan masyarakat, perempuan banyak berinteraksi dalam kelompokkelompok informal.

Dalam pengambilan keputusan, didominasi oleh istri atau pengusaha batik itu sendiri. Hal ini dikarenakan segala sesuatu mengenai produksi batik yang memegang kendali adalah istri karena istri atau pengusaha batik yang lebih mengetahui dunia perbatikan dari awal produksi hingga 
pengaturan keungan usaha. Pengalokasian waktu yang mereka habiskan untuk kegiatan rumah tangga dan usaha bahwa ternyata dalam alokasi waktu pun, perempuan lah yang lebih banyak mengalokasikan waktu baik dalam kegiatan rumah tangga (reproduktif), maupun kegiatan mencari produktif.

\section{Daftar Pustaka}

Boserup, Ester. 1984. Peranan Wanita dalam Perkembangan Ekonomi. Jakarta: Gramedia.

Moser, Caroline O.N. 1991. Gender Planning and Development: Theory, Practice and Training. London Routledge.

McClelland, David C. 1971. The Achievement Motive in Economic Growth, dalam Finkle \& Gable (eds). Hal 83-100.

Rajani, N dan Saradi D. 2008. Woman Entrepreneurship and Support system. Kamla Raj Swa Magazine 23/XVIII/5-17 NOVEMBER 2002. "50 Top Management Enterprise".

Sadli, Saparinah. 2010. Berbeda Tetapi Setara, Pemikiran tentang Kajian Perempuan. Jakarta: Buku Kompas.

Suhendi, Hendi. 2001. Pengantar Studi Sosiologi Keluarga. Bandung: Pustaka Setia.

Stoler, Ann. 1984. "Struktur Kelas dan Otonomi Wanita di Pedesaan Jawa", dalam Koentjaraningrat ed., Masalah-masalah Pembangunan. Jakarta: LP3ES.

Wiryanto, Teguh Adi. 2011. Analisis Industri Batik Tulis di Kelurahan Kalinyamat Wetan dan Kelurahan Bandung Kota Tegal. Skripsi Fakultas Ekonomi dan Bisnis Universitas Diponegoro Semarang.

Wisadirana, Darsono. 2004. Sosiologi Pedesaan. Malang: UMM Press.

Yahya, Amri. 1971.Seni Lukis Batik Sebagai Sarana Peningkatan Apresiasi Seni Lukis Kontemporer. Fakultas Keguruan Ilmu Seni: IKIP Yogyakarta. 